\title{
KEMAMPUAN PENANGANAN TERHADAP ANCAMAN BENCANA TSUNAMI DI WILAYAH PESISIR KOTA CILEGON
}

\section{CAPACITY AGAINST TSUNAMI DISASTER IN THE COASTAL AREA OF CILEGON}

\author{
Diyah Krisna Yuliana, Iwan G. Tejakusuma ${ }^{1}$
}

\begin{abstract}
ABSTRAK: Wilayah pesisir Kota Cilegon merupakan daerah rawan gempa dan tsunami, karena posisinya yang berbatasan langsung dengan Selat Sunda yang memiliki bahaya gempa dan dekat dengan Gunung Anak Krakatau. Pada tahun 1883 pernah terjadi tsunami besar akibat letusan Gunung Krakatau yang telah memakan korban sekitar 36.000 jiwa. Risiko bencana tsunami akan sangat besar bagi Kota Cilegon karena terletak di wilayah pesisir dengan tingkat kepadatan penduduk dan aktivitas perekonomian yang cukup tinggi. Risiko bencana yang tinggi dapat diminimalisir jika suatu wilayah memiliki tingkat kemampuan penanganan atau kapasitas yang tinggi. Oleh karena itu kajian tentang kemampuan penanganan terhadap bencana tsunami di kota ini menjadi sangat penting. Penilaian kemampuan penanganan terhadap ancaman bencana tsunami ini dilakukan dengan menggunakan metode MCE (Multi Criteria Evaluation) dan teknik GIS (Geographical Information System). Kesehatan, kesiapsiagaan dan jumlah penduduk bekerja adalah tiga indikator penting yang digunakan dalam penilaian kemampuan penanganan di wilayah pesisir Kota Cilegon. Berdasarkan analisis MCE dan SIG diketahui bahwa Desa atau Kelurahan Randakari dan Kubangsari adalah desa atau kelurahan yang memiliki kemampuan penanganan terhadap bencana tsunami yang paling tinggi.
\end{abstract}

Kata kunci: kemampuan penanganan, bencana tsunami, MCE, SIG, pesisir Cilegon.

ABSTRACT: The coastal area Cilegon city is prone to earthquakes and tsunamis, because of its position directly adjacent to the Sunda Strait which has the potential of earthquakes and close to Mount Anak Krakatau. In 1883 Mount Krakatau erupted which also generating large tsunami waves and has killed about 36,000 people living in the adjacent coastal areas. The risk of tsunami disaster is high for the city of Cilegon because it is located in the coastal areas with high population density and economic activity. High disaster risk can be minimised if an area has a high level of capacity to cope with the disaster. Therefore, the study of capacity to tsunami disaster for the city are very important. Assessment of capacities from the threat of the tsunami disaster is done by using MCE (Multi Criteria Evaluation) and GIS (Geographical Information System) technique. Health, preparedness and the number of working population are three important indicators that are used in the assessment. Based on MCE and GIS analysis, Randakari and Kubangsari Villages have the highest capacity against tsunami disaster.

Keywords: capacity, tsunami disaster, MCE, SIG, coastal Cilegon. 


\section{PENDAHULUAN}

Secara geografis, Indonesia merupakan negara kepulauan yang terletak pada pertemuan empat lempeng tektonik yaitu Lempeng Indo-Australia, Lempeng Eurasia, Lempeng Pasifik dan Lempeng Filipina. Lempeng tersebut saling bertumbukan satu dengan yang lain sehingga menimbulkan aktifitas tektonik dan vulkanik yang sangat tinggi berupa zona-zona patahan aktif dan sebaran gunung api (Latief et al, 2010). Kondisi tersebut sangat berpotensi sekaligus rawan bencana seperti letusan gunung berapi, gempa bumi, tsunami, banjir dan tanah longsor. Gempa bumi yang disebabkan karena interaksi lempeng tektonik dapat menimbulkan gelombang pasang apabila terjadi di samudera. Dengan wilayah yang sangat dipengaruhi oleh pergerakan lempeng tektonik ini, Indonesia sering mengalami tsunami. Pesisir merupakan wilayah yang paling padat dihuni oleh manusia serta tempat berlangsungnya berbagai macam kegiatan pembangunan. Data statistik kependudukan menunjukkan bahwa hampir $60 \%$ penduduk Indonesia menempati wilayah pesisir. Sebagian besar pusat-pusat pertumbuhan di Indonesia juga berlokasi di wilayah pesisir seperti Jakarta, Surabaya, Makasar dan lain-lain. Wilayah pesisir sebagai daerah hunian dan pusat aktivitas masyarakat merupakan kawasan yang rawan bencana. Tingginya frekuensi tsunami yang menerjang pesisir Indonesia serta besarnya kerugian yang ditimbulkan baik jiwa manusia maupun harta benda karena ancaman tsunami sangat besar, maka sangat perlu untuk memahami fenomena bahaya tsunami (Latief et al, 2010). Selat Sunda terletak pada kawasan transisi antara segmen Sumatera dan segmen Jawa dari Busur Sunda, yang juga merupakan

\footnotetext{
1 PTRRB - TPSA, Badan Pengkajian dan Penerapan Teknologi (BPPT)

JI. M. H. Thamrin No.8 Jakarta 10340

email:diyah.krisna@bppt.go.id, itejakusuma@yahoo.com
}

daerah di Indonesia yang sangat aktif dalam hal aktivitas vulkanik, kegempaan dan pergerakan tektonik vertikal. Zona penunjaman di selatan Pulau Jawa, segmen Jawa dari Busur Sunda yang memanjang dari Selat Sunda sampai Cekungan Bali di Timur. Tsunami yang terjadi di Selat Sunda adalah sebagai akibat dari gempa tektonik di laut ataupun akibat letusan gunung api. Selain itu, longsor di daerah graben Selat Sunda yang dipicu oleh gempabumi merupakan salah satu potensi terjadinya tsunami di kawasan ini. Catatan sejarah dan rekaman alat juga menunjukan bahwa bencana gempabumi dan tsunami sudah sering terjadi di Selat Sunda, baik yang diakibatkan oleh kondisi tektonik maupun kondisi vulkanik.

Bencana terbesar yang pernah terjadi di wilayah pesisir Kota Cilegon adalah terjadinya letusan Gunung Krakatau pada27 Agustus 1883 sekitar jam 10:02, yang merupakan kombinasi ledakan, subsiden, runtuhan kaldera, longsor dan longsor bagian gunungapi yang berada di bawah laut (Carayannis, 2003). Letusan tersebut menyebabkan tsunami setinggi 15 40 meter sehingga menghancurkan kota dan desa di kawasan Selat Sunda termasuk Kota Cilegon serta mengakibatkan hilangnya nyawa lebih dari 36.000 orang. Aktivitas gunungapi berlanjut dan menghasilkan Gunung Anak Krakatau yang telah tumbuh sejak letusannya yang terakhir pada 27 Agustus 1883.

Kota Cilegon yang terletak di Provinsi Banten merupakan pintu gerbang utama yang menghubungkan sistem Pulau Jawa dengan Pulau Sumatera sehingga kedudukan Kota Cilegon memiliki nilai geostrategis yang sangat penting baik dalam konstelasi lokal, regional, maupun nasional. Selain itu, posisi wilayah pesisirnya yang berbatasan langsung dengan Selat Sunda memiliki risiko tinggi terhadap ancaman bencana tsunami.

Risiko bencana adalah potensi kerugian akibat bencana yang dapat berupa korban jiwa, status kesehatan, mata pencaharian, aset dan jasa yang terjadi pada suatu komunitas tertentu atau masyarakat selama beberapa periode waktu tertentu di masa depan (UNISDR, 2009). Pada dasarnya, risiko dari suatu 
bencana memiliki tiga variabel (UN-ISDR, 2004), yaitu:

a. jenis ancaman/bahaya

b. aspek kerentanan

c. aspek kemampuan penanganan

Risiko berbanding lurus dengan bahaya dan tingkat kerentanan terhadap tsunami, serta berbanding terbalik dengan kemampuan (kapasitas) dalam menghadapi tsunami. Risiko tsunami ada hanya jika ada masyarakat yang rentan di dalam daerah bahaya tsunami. Bahaya bencana dan kerentanan sebagai faktor yang meningkatkan risiko, sedangkan kemampuan penanganan sebagai faktor yang menurangi nilai risiko. Interaksi antara bahaya (hazard), kerentanan (vulnerability), kapasitas penanggulangan (capacity) dan risiko (risk) dirumuskan pada persamaan di bawah ini (UN-ISDR, 2002):

Risiko $(\mathrm{R})=$ Bahaya $(\mathrm{H}) \quad \mathrm{X}$ Kerentanan $(\mathrm{V})$ Kemampuan penanganan (C)

Risiko bencana yang tinggi dapat diminimalisir jika suatu wilayah memiliki tingkat kemampuan penanganan atau kapasitas yang tinggi. Oleh karena itu kajian tentang kemampuan penanganan atau kapasitas terhadap bencana tsunami di kota ini menjadi sangat penting. Post et al (2007) menyatakan bahwa pengkajian kerentanan dan pemodelan risiko merupakan komponen yang penting dalam sistem peringatan dini tsunami yang menyeluruh sehingga secara signifikan akan menyumbangkan pada pengurangan risiko bencana.

$$
\text { Menurut UN-ISDR }
$$

kemampuan penanganan

(2009), (coping capacity) berarti kemampuan masyarakat, organisasi, dan sistem untuk menggunakan ketrampilan dan sumberdaya yang ada dalam menghadapi dan mengelola kondisi merugikan pada keadaan darurat atau bencana. Kemampuan penanganan dipahami sebagai kemampuan seseorang untuk melakukan tindakan pada waktu yang singkat sehingga dapat meningkatkan kemampuannya untuk beradaptasi dengan perubahan dalam jangka waktu yang lama. Hal tersebut tentukan oleh karakteristik sosial ekonomi dan demografi dari populasi serta kerangka umum sosial, ekonomi dan politik (Eriksen, et al., 2005; Klepeis and Laris, 2006 dalam Lazarus, 2007).

Dalam hal ini, penelitian tentang kemampuan penanganan terhadap ancaman bencana tsunami dilakukan di wilayah pesisir Kota Cilegon yang terdiri dari empat kecamatan yaitu: Kecamatan Ciwandan, Kecamatan Citangkil, Kecamatan Grogol dan Kecamatan Pulomerak. Secara geografis keempat kecamatan ini memiliki wilayah pesisir yang berhadapan langsung dengan Selat Sunda.

Kemampuan

penanganan menggunakan tiga komponen penilaian yaitu kesehatan, kesiapan bencana, dan jumlah penduduk bekerja. Kemampuan penanganan kesehatan menggunakan 2 indikator penilaian yaitu jumlah fasilitas kesehatan dan jumlah tenaga medis. Sosialisasi bencana dan sistem peringatan dini merupakan indikator penilaian kemampuan penanganan kesiapan bencana. Komponen lainnya, yaitu jumlah penduduk bekerja dihitung dalam proporsi terhadap jumlah total penduduk.

\begin{tabular}{cllll}
\hline No & Bahan & Spesifikasi & Sumber & Format Data \\
\hline 1. & Peta RBI Kota Cilegon skala 1:25.000 & Sekunder & BIG & digital \\
\hline 2. & Data Sensus Penduduk tahun 2010 & Sekunder & dibi.bnpb.go.id & digital \\
\hline 3. & Data Potensi Desa tahun 2011 & Sekunder & dibi.bnpb.go.id & digital \\
\hline 4. & Kota Cilegon dalam Angka tahun 2012 & Sekunder & BPS Cilegon & digital \\
\hline
\end{tabular}




\section{METODE}

Penelitian kemampuan penanganan terhadap ancaman bencana tsunami di Kota Cilegon dilakukan dengan metode seperti yang diterangkan pada berikut ini.

- Pengumpulan Data Sekunder.

Pengumpulan data sekunder yang digunakan serta sumbernya sebagai berikut: penanganan di setiap unit analisis yang kemudian nilai-nilai tersebut distandarkan dengan metode standarisasi nilai maksimum, dimana mengubah nilai tertinggi menjadi 1 , nilai terendah menjadi 0 , dan nilai lainnya diubah menjadi nilai diantara 0 dan 1 sesuai dengan distribusi nilai tersebut. Penilaian bobot faktor dan kriteria kemampuan penanganan dapat dilihat pada tabel di bawah ini.

Tabel 1. Penilaian bobot faktor dan kriteria kemampuan penanganan.

\begin{tabular}{|c|c|c|c|c|c|c|}
\hline Kriteria & $\begin{array}{l}\text { Indikator } \\
\text { Penilaian }\end{array}$ & $\begin{array}{c}\text { Metode } \\
\text { Pembobotan }\end{array}$ & $\begin{array}{l}\text { Bobot } \\
\text { Faktor }\end{array}$ & $\begin{array}{c}\text { Komponen } \\
\text { penilaian }\end{array}$ & $\begin{array}{c}\text { Metode } \\
\text { Pembobotan }\end{array}$ & $\begin{array}{c}\text { Bobot } \\
\text { kriteria }\end{array}$ \\
\hline \multirow{5}{*}{$\begin{array}{l}\text { Kemampuan } \\
\text { penanganan }\end{array}$} & $\begin{array}{l}\% \text { penduduk } \\
\text { bekerja }\end{array}$ & Metode direct & 1 & $\begin{array}{l}\text { Penduduk } \\
\text { bekerja }\end{array}$ & \multirow{5}{*}{$\begin{array}{l}\text { Metode } \\
\text { pairwise }\end{array}$} & \multirow{5}{*}{1} \\
\hline & $\begin{array}{l}\text { Fasilitas } \\
\text { kesehatan }\end{array}$ & \multirow{2}{*}{$\begin{array}{l}\text { Metode } \\
\text { pairwise }\end{array}$} & \multirow{2}{*}{1} & \multirow{2}{*}{ Kesehatan } & & \\
\hline & $\begin{array}{l}\text { Jumlah } \\
\text { tenaga medis }\end{array}$ & & & & & \\
\hline & $\begin{array}{l}\text { Sosialisasi } \\
\text { bencana }\end{array}$ & \multirow{2}{*}{$\begin{array}{l}\text { Metode } \\
\text { pairwise }\end{array}$} & \multirow{2}{*}{1} & \multirow{2}{*}{$\begin{array}{l}\text { Kesiapan } \\
\text { bencana }\end{array}$} & & \\
\hline & $\begin{array}{l}\text { Sistem } \\
\text { peringatan dini }\end{array}$ & & & & & \\
\hline
\end{tabular}

- Analisis Data.

Analisis yang dilakukan dalam dalam penelitian ini adalah:

- Mengubah semua data sekunder yang telah didapatkan kemudian ditransformasi menjadi data spatial. Selanjutnya setelah semua data menjadi data spatial, proses berikutnya adalah mengelompokkan data menjadi 3 kelompok berdasarkan komponen kemampuan penanganan, yaitu kelompok data komponen kesehatan, kesiapan bencana, dan jumlah penduduk bekerja.

- Melakukan penilaian kemampuan penanganan (kapasitas) di wilayah pesisir Kota Cilegon berdasarkan hasil dari tahap 1 dengan menggunakan analisis MCE (Multi Criteria Evaluation) dan teknik GIS (Geographical Information System) menghitung nilai kemampuan

\section{Hasil Dan Pembahasan}

Kemampuan penanganan merupakan komponen yang mengurangi risiko bencana. Data kemampuan penanganan menggunakan beberapa data yaitu keberadaan fasilitas kesehatan (rumah sakit, rumah sakit bersalin, poliklinik, puskesmas, puskesmas pembantu dan puskesdes (pusat kesehatan desa), jumlah tenaga medis (dokter, dokter gigi, bidan dan tenaga medis lainnya), ada tidaknya sosialisasi bencana dan sistem peringatan dini serta persentase penduduk bekerja. Keberadaan fasilitas kesehatan dan jumlah tenaga medis dimasukkan sebagai indikator kesehatan dalam kemampuan penanganan. Data yang digunakan bersumber dari Sensus Penduduk Tahun 2010 dan Potensi Desa Tahun 2011 dari Biro Pusat Statistik.

Data sosialisasi bencana dan keberadaan sistem peringatan dini juga 
diperoleh dari Potensi Desa Tahun 2011. Data tersebutmerupakan indikatorkesiapanbencana dalam kemampuan penanganan.

Persentase jumlah penduduk yang bekerja dinilai sebagai faktor yang dapat mengurangi risiko bencana tsunami. Semakin tinggi persentase jumlah penduduk yang bekerja, maka semakin tinggi juga nilai kemampuan penanganan (Mardiatno dan Yurdinus, 2010). Rumus dalam menentukan persentase penduduk yang bekerja adalah:

Persentase Penduduk Bekerja $=\frac{\text { (jumlah penduduk bekerja) }}{\text { (jumlah total penduduk })} \times 100 \%$

\subsection{Hasil Bobot Untuk Indikator Kemampuan Penanganan}

Kemampuan penanganan kesehatan merupakan hasil kombinasi antara parameter jumlah fasilitas kesehatan dan jumlah tenaga medis. Pembobotan antara dua indikator ini dilakukan dengan metode pairwise. Indikator jumlah fasilitas kesehatan dinilai memiliki pengaruh yang lebih besar terhadap kemampuan penanganan kesehatan dibandingkan jumlah tenaga medis.

Sosialisasi bencana dan sistem peringatan dini dikombinasikan untuk memperoleh kemampuan penanganan kesiapan bencana. Metode penentuan bobot yang digunakan adalah pairwise. Pengaruh sosialisasi bencana dinilai lebih besar dalam pengaruhnya terhadap kemampuan penanganan kesiapan bencana dibandingkan dengan sistem peringatan dini.

Bobot indikator kesehatan, kesiapan bencana, dan persentase penduduk bekerja dalam membangun nilai kemampuan penanganan total ditentukan dengan metode pairwise. Indikator kesiapan bencana dinilai memiliki pengaruh yang paling penting terhadap kemampuan penanganan total. Indikator kesehatan dan memiliki pengaruh yang lebih besar terhadap kemampuan penanganan total dibandingkan dengan jumlah penduduk bekerja. Tabel 2 menyajikan nilai pembobotan kemampuan penanganan.
Tabel 2. Nilai Pembobotan Kemampuan Penanganan.

\begin{tabular}{|c|c|c|c|c|c|}
\hline Indikator & Bobot & $\begin{array}{c}\text { Indikator } \\
\text { Kemampuan } \\
\text { Penanganan }\end{array}$ & Bobot & $\begin{array}{l}\text { Kemampuan } \\
\text { Penanganan }\end{array}$ & Bobot \\
\hline $\begin{array}{l}\text { Fasilitas } \\
\text { kesehatan }\end{array}$ & 0,675 & \multirow[b]{2}{*}{ Kesehatan } & \multirow[b]{2}{*}{0,258} & \multirow{5}{*}{$\begin{array}{l}\text { Kemampuan } \\
\text { Penanganan } \\
\text { Total }\end{array}$} & \multirow{5}{*}{1} \\
\hline $\begin{array}{l}\text { Jumlah } \\
\text { tenaga } \\
\text { medis }\end{array}$ & 0,325 & & & & \\
\hline $\begin{array}{l}\text { Sosialisasi } \\
\text { bencana }\end{array}$ & 0,591 & \multirow[b]{2}{*}{$\begin{array}{l}\text { Kesiapan } \\
\text { Bencana }\end{array}$} & \multirow[b]{2}{*}{0,595} & & \\
\hline $\begin{array}{l}\text { System } \\
\text { peringatan } \\
\text { dini } \\
\end{array}$ & 0,409 & & & & \\
\hline Penduduk b & kerja & & 0,147 & & \\
\hline
\end{tabular}

Nilai inkonsistensi rasio pada pairwise pembobotan kemampuan penanganan adalah 0,02 nilai ini bisa diterima karena nilainya lebih rendah dari 0,1 . Indikator yang memberi pengaruh terbesar terhadap hasil akhir perhitungan adalah kesiapan bencana dilihat dari bobot dan nilai indikator yang tertinggi sehingga memberikan hasil kemampuan penanganan yang tinggi juga.

\subsection{Tingkat Kemampuan Penanganan Dalam Hal Kesehatan}

Komponen kesehatan menggunakan dua indikator penilaian yaitu jumlah fasilitas kesehatan dan jumlah tenaga medis. Indikator fasilitas kesehatan diberi bobot 0,675 dan indikator tenaga medis diberi bobot 0,325. Sedangkan komponen kesehatan secara keseluruhan diberi bobot 0,258. Bobot indikator dan komponen ini digunakan untuk menentukan saat perhitungan nilai kemampuan penanganan total pada tahap akhir penilaian kemampuan penanganan. Pemberian bobot tersebut didasarkan pada hasil kuesioner. Dapat disimpulkan bahwa indikator jumlah fasilitas kesehatan memiliki pengaruh yang lebih penting dibandingkan dengan indikator jumlah tenaga medis terhadap kemampuan penanganan kesehatan.

Metode standarisasi maksimum dipilih untuk mengubah nilai kemampuan penanganan jumlah fasilitas kesehatan dan jumlah tenaga medis menjadi nilai antara 0 
Tabel 3. Standarisasi Nilai Komponen Kesehatan.

\begin{tabular}{|c|c|c|c|c|c|}
\hline \multirow[b]{2}{*}{ Kecamatan } & \multirow{2}{*}{$\begin{array}{l}\text { Desa/ } \\
\text { Kelurahan }\end{array}$} & \multicolumn{4}{|c|}{ Kesehatan } \\
\hline & & $\begin{array}{c}\text { Jumlah Fasilitas } \\
\text { kesehatan }\end{array}$ & $\begin{array}{c}\text { Nilai } \\
\text { Standarisasi }\end{array}$ & $\begin{array}{c}\text { Jumlah Tenaga } \\
\text { Medis }\end{array}$ & $\begin{array}{c}\text { Nilai } \\
\text { Standarisasi }\end{array}$ \\
\hline \multirow[t]{6}{*}{ Ciwandan } & Gunung Sugih & 1 & 0,14 & 2 & 0,1 \\
\hline & Kepuh & 1 & 0,14 & 2 & 0,1 \\
\hline & Randakari & 1 & 0,14 & 3 & 0,15 \\
\hline & Tegalratu & 1 & 0,14 & 3 & 0,15 \\
\hline & Banjar Negara & 0 & 0 & 1 & 0,05 \\
\hline & Kubangsari & 1 & 0,14 & 4 & 0,2 \\
\hline \multirow[t]{7}{*}{ Citangkil } & Deringo & 0 & 0 & 4 & 0,2 \\
\hline & Lebak Denok & 1 & 0,14 & 4 & 0,2 \\
\hline & Taman Baru & 3 & 0,43 & 7 & 0,35 \\
\hline & Citangkil & 0 & 0 & 12 & 0,6 \\
\hline & Kebonsari & 3 & 0,43 & 7 & 0,35 \\
\hline & Warnasari & 1 & 0.14 & 20 & 1 \\
\hline & Samang Raya & 2 & 0,29 & 9 & 0,45 \\
\hline \multirow[t]{4}{*}{ Gerogol } & Kotasari & 4 & 0,57 & 10 & 0,5 \\
\hline & Gerogol & 1 & 0,14 & 1 & 0,05 \\
\hline & Rawa Arum & 7 & 1 & 7 & 0,35 \\
\hline & Gerem & 2 & 0,29 & 6 & 0,3 \\
\hline \multirow[t]{4}{*}{ Pulomerak } & Mekarsari & 1 & 0,14 & 4 & 0,2 \\
\hline & Tamansari & 0 & 0 & 5 & 0,25 \\
\hline & Lebak Gede & 2 & 0,29 & 4 & 0,2 \\
\hline & Suralaya & 2 & 0,29 & 1 & 0,05 \\
\hline
\end{tabular}

(Hasil Pengolahan Data)

dan 1. Nilai 0 berarti tidak memiliki kemampuan penanganan, sedangkan nilai 1 berarti nilai kemampuan penanganan tertinggi. Nilai standarisasi disajikan dalam Tabel 3 di atas.

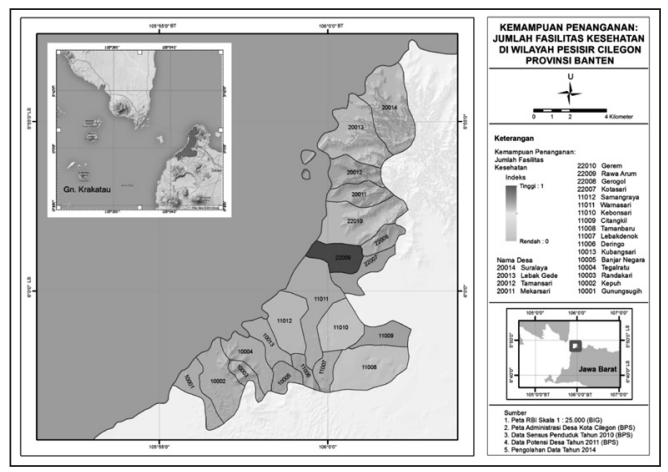

Gambar 1. Peta Kemampuan Penanganan: Fasilitas Kesehatan.

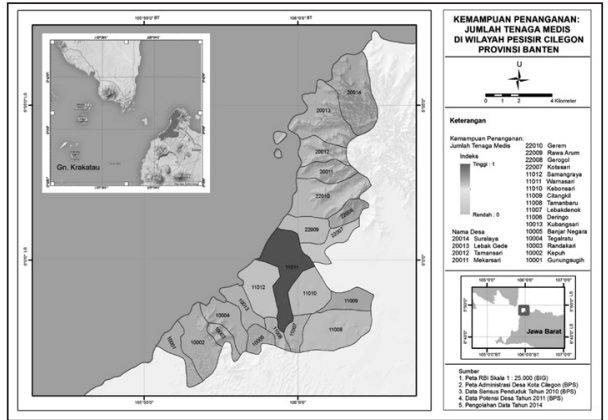

Gambar 2. Peta Kemampuan Penanganan: Jumlah Tenaga Medis.

Berdasarkan jumlah fasilitas kesehatan terdapat 3 desa/kelurahan yang tidak memiliki fasilitas kesehatan, yaitu Kelurahan Banjar Negara, Kelurahan Citangkil dan Kelurahan Taman Sari. Kelurahan yang memiliki fasilitas 
kesehatan terbanyak adalah Kelurahan Rawa Arum yang terdapat di Kecamatan Gerogol, dimana memiliki 7 fasilitas kesehatan yang terdiri dari 5 RS bersalin, 1 poliklinik dan 1 poskesdes.

Jumlah tenaga medis terbanyak terdapat di Kelurahan Warnasari yang berjumlah 20 orang, sedangkan jumlah tenaga medis yang paling sedikit terdapat di tiga kelurahan yang masing-masing hanya memiliki 1 orang tenaga medis, yaitu Kelurahan Banjar Negara dan Kelurahan Gerogol berupa 1 bidan dan Kelurahan Suralaya berupa 1 dokter.

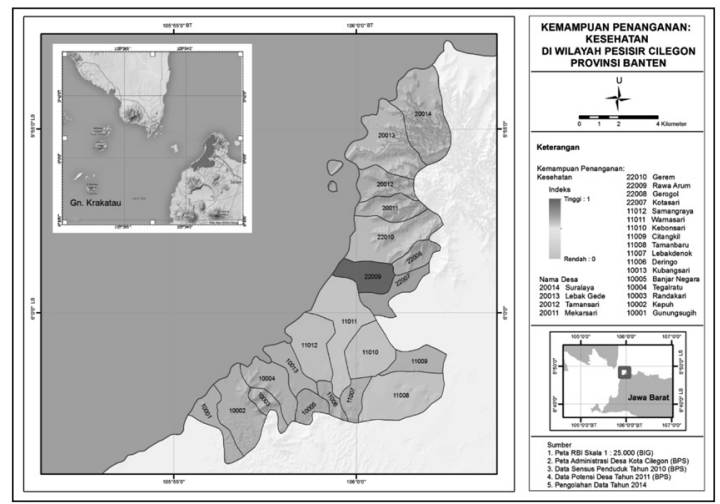

Gambar 3. Peta Kemampuan Penanganan: Kesehatan.

Untuk kombinasi antara indikator fasilitas kesehatan dan indikator tenaga medis yang menjadi komposisi pada aspek kemampuan penanganan kesehatan, diketahui bahwa Kelurahan Rawa Arum merupakan desa/ kelurahan yang memiliki kemampuan penanganan kesehatan yang paling tinggi. Hal ini disebabkan karena kelurahan ini memiliki jumlah faskes yang lebih banyak jika dibandingkan dengan desa/kelurahan lainnya. Desa Gerogol memiliki kemampuan penanganan kesehatan yang paling rendah, hal ini dikarenakan sedikitnya fasilitas kesehatan dan tenaga medis yang ada di desa tersebut padahal Desa Gerogol berada di kecamatan yang sama dengan Kelurahan Rawa Arum, yaitu Kecamatan Gerogol.

\subsection{Tingkat Kemampuan Penanganan Dalam Hal Kesiapan Bencana}

$\begin{array}{ccc}\text { Komponen } & \text { kesiapan bencana } \\ \text { menggunakan dua indikator penilaian }\end{array}$ yaitu jumlah sosialisasi bencana dan sistem peringatan dini. Indikator sosialisasi bencana diberi bobot 0,591 dan indikator sistem peringatan dini diberi bobot 0,409. Sedangkan komponen kesiapan bencana secara keseluruhan diberi bobot 0,595. Bobot indikator dan komponen ini digunakan untuk menentukan saat perhitungan nilai kemampuan penanganan total pada tahap akhir penilaian kemampuan penanganan. Pemberian bobot tersebut didasarkan pada hasil kuesioner. Dapat disimpulkan bahwa indikator sosialisasi bencana memiliki pengaruh yang lebih penting dibandingkan dengan indikator sistem peringatan dini terhadap kemampuan penanganan kesiapan bencana. Kegiatan yang dimasukkan sebagai sosialisasi bencana adalah kegiatan simulasi bencana tsunami (tsunami drill). Kegiatan tersebut memberikan pengetahuan kepada penduduk tentang informasi dan cara menyelamatkan diri (evakuasi) dari bencana tsunami.

Standarisasi nilai untuk parameter kesiapan bencana diberi nilai 0 dan 1 . Nilai 0 berarti tidak pernah dilakukan/tidak ada, sedangkan nilai 1 berarti pernah dilakukan/ ada.

Tabel 4. Standarisasi Nilai Komponen Kesiapan Bencana.

\begin{tabular}{|c|c|c|c|c|c|}
\hline \multirow[b]{2}{*}{ Kecamatan } & \multirow[b]{2}{*}{$\begin{array}{c}\text { Desa/ } \\
\text { Kelurahan }\end{array}$} & \multicolumn{4}{|c|}{ Kesehatan } \\
\hline & & $\begin{array}{c}\text { Jumlah Fasilitas } \\
\text { kesehatan }\end{array}$ & $\begin{array}{c}\text { Nilai } \\
\text { Standarisasi }\end{array}$ & $\begin{array}{l}\text { Jumlah Tenaga } \\
\text { Medis }\end{array}$ & $\begin{array}{c}\text { Nilai } \\
\text { Standarisasi }\end{array}$ \\
\hline \multirow[t]{3}{*}{ Ciwandan } & Gunung Sugih & Ada & 1 & Tidak ada & 0 \\
\hline & Kepuh & Ada & 1 & Tidak ada & 0 \\
\hline & Randakari & Ada & 1 & Tidak ada & 0 \\
\hline
\end{tabular}




\begin{tabular}{|l|l|l|l|l|l|}
\hline \multirow{4}{*}{} & Tegalratu & Ada & 1 & Tidak ada & 0 \\
\cline { 2 - 6 } & Banjar Negara & Ada & 1 & Tidak ada & 0 \\
\cline { 2 - 6 } & Kubangsari & Ada & 1 & Tidak ada & 0 \\
\hline \multirow{4}{*}{ Citangkil } & Deringo & Tidak ada & 0 & Tidak ada & 0 \\
\cline { 2 - 6 } & Lebak Denok & Tidak ada & 0 & Tidak ada & 0 \\
\cline { 2 - 6 } & Taman Baru & Tidak ada & 0 & Tidak ada & 0 \\
\cline { 2 - 6 } & Citangkil & Tidak ada & 0 & Tidak ada & 0 \\
\cline { 2 - 6 } & Kebonsari & Tidak ada & 0 & Tidak ada & 0 \\
\cline { 2 - 6 } & Warnasari & Tidak ada & 0 & Tidak ada & 0 \\
\cline { 2 - 6 } & Samang Raya & Tidak ada & 0 & Tidak ada & 0 \\
\hline \multirow{5}{*}{ Gerogol } & Kotasari & Tidak ada & 0 & Tidak ada & 0 \\
\cline { 2 - 6 } & Gerogol & Tidak ada & 0 & Tidak ada & 0 \\
\cline { 2 - 6 } & Rawa Arum & Tidak ada & 0 & Tidak ada & 0 \\
\cline { 2 - 6 } & Gerem & Tidak ada & 0 & Tidak ada & 0 \\
\hline Pulomerak & Mekarsari & Tidak ada & 0 & Tidak ada & 0 \\
\cline { 2 - 6 } & Tamansari & Tidak ada & 0 & Tidak ada & 0 \\
\cline { 2 - 6 } & Lebak Gede & Tidak ada & 0 & Tidak ada & 0 \\
\cline { 2 - 6 } & Suralaya & Tidak ada & 0 & Tidak ada & 0 \\
\hline
\end{tabular}

(Hasil Pengolahan Data)

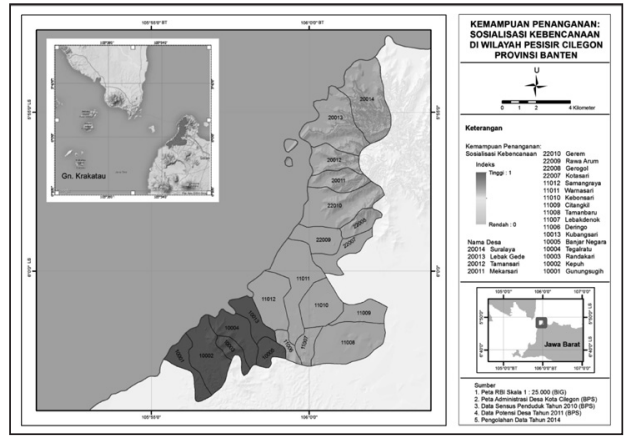

Gambar 4. Peta Kemampuan Penanganan: Sosialisasi Kebencanaan.

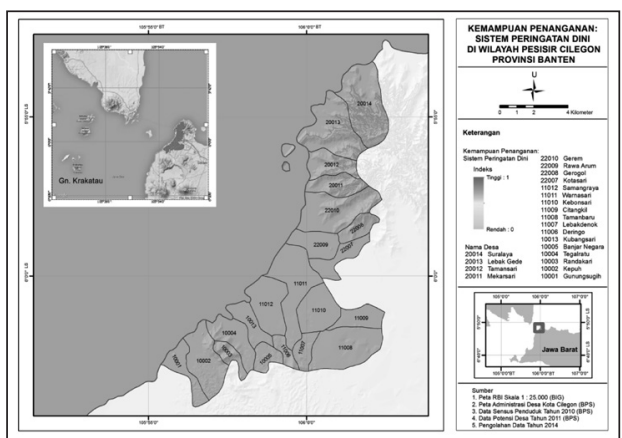

Gambar 5. Peta Kemampuan Penanganan: Sistem Peringatan Dini.
Kota Cilegon belum memiliki Badan Penanggulangan Bencana Daerah (BPBD), sehingga data sosialisasi bencana dan sistem peringatan dini hanya bisa diperoleh dari data Potensi Desa (Podes) Tahun 2011 dan pengamatan langsung. Berdasarkan data yang diperoleh, yang pernah melakukan kegiatan sosialisasibencana adalah hanya desa/kelurahan yang terdapat di Kecamatan Ciwandan, hal ini dapat dibuktikan dengan pernah diadakannya Tsunami Drill Anyer - Cilegon pada tahun 2007 yang didanai oleh Kementrian RISTEK dan BNPB, serta yang data yang paling terbaru menginformasikan bahwa tanggal 5 November 2014 di Kecamatan Ciwandan juga baru saja dilaksanakan "Tsunami Drill Technical Assistant in Petrochemical Industries" yang diadakan oleh Ciwandan Emergency Response Team yang bekerja sama dengan BPPT. Kecamatan Ciwandan ini memiliki industri kimia terbesar di Asia Tenggara (PT. Chandra Asri Petrochemical) sehingga sangat rawan sekali jika terjadi bencana tsunami, terutama untuk bahaya ikutannya berupa ledakan dan pencemaran lingkungan yang diakibatkan meledaknya bahan-bahan kimia tersebut. 
Untuk sistem peringatan dini, berdasarkan data yang diperoleh, ternyata belum ada di empat kecamatan ini.

Untuk kombinasi antara indikator sosialisasi bencana dan indikator sistem peringatan dini (early warning system) yang menjadi komposisi pada aspek kemampuan penanganan kesiapan bencana, diketahui bahwa semua desa/kelurahan di Kecamatan Ciwandan memiliki kemampuan penanganan kesiapan bencana yang paling tinggi. Hal ini disebabkan karena di kecamatan ini memiliki kawasan industri, yang mana lebih banyak terdapat industri kimia jika dibandingkan dengan kecamatan lainnya sehingga di kawasan industri kimia tersebut telah memiliki tim khusus untuk mempersiapkan atau mengantisipasi jika bencana terjadi.

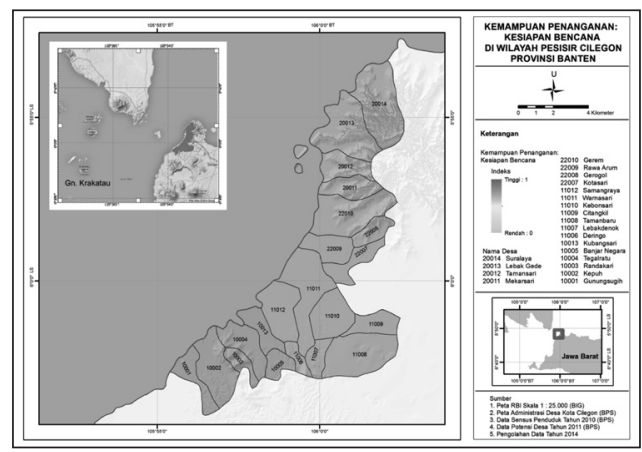

Gambar 6. Peta Kemampuan Penanganan: Kesiapan Bencana.

\subsection{Tingkat Kemampuan Penanganan Dalam Hal Jumlah Penduduk Bekerja}

$$
\text { Jumlah penduduk bekerja }
$$
dihitung secara proporsional dengan cara membandingkannya terhadap jumlah total penduduk. Hal ini berfungsi agar perbandingan kemampuan penanganan di tiap desa/kelurahan memiliki proporsi yang sama terhadap penduduk yang ada di desa/ kelurahan tersebut. Semakin tinggi persentase penduduk bekerja berarti kemampuan penanganannya dinilai semakin tinggi. Indikator ini diberi bobot 0,147. Bobot indikator ini untuk menentukan saat perhitungan nilai kemampuan penanganan total pada tahap akhir penilaian kemampuan penanganan. Pemberian bobot tersebut didasarkan pada hasil kuesioner.

Metode standarisasi maksimum dipilih untuk mengubah nilai kemampuan penanganan jumlah penduduk bekerja menjadi nilai antara 0 dan 1 . Nilai 0 berarti tidak memiliki kemampuan penanganan, sedangkan nilai 1 berarti nilai kemampuan penanganan tertinggi. Nilai standarisasi disajikan dalam Tabel 5.

Dari data tersebut diketahui bahwa persentase penduduk bekerja tertinggi terdapat di Kelurahan Taman Baru yaitu 40,86\%. Kelurahan Taman Baru memiliki 2.536 dari 6.207 jiwa penduduk yang

Tabel 5. Standarisasi Nilai Persentase Jumlah Penduduk Bekerja.

\begin{tabular}{|l|l|c|c|}
\hline Kecamatan & \multicolumn{1}{|c|}{ Desa/Kelurahan } & Presentase & Nilai Standarisasi \\
\hline \multirow{3}{*}{ Ciwandan } & Gunung Sugih & 32,46 & 0.79 \\
\cline { 2 - 4 } & Kepuh & 33,87 & 0.83 \\
\cline { 2 - 4 } & Randakari & 35,33 & 0.86 \\
\hline & Tegalratu & 31,48 & 0.77 \\
\hline & Banjar Negara & 27,27 & 0.67 \\
\hline & Kubangsari & 34,61 & 0.85 \\
\hline & Deringo & 36,28 & 0.89 \\
\hline & Lebak Denok & 37,27 & 0.91 \\
\hline & Taman Baru & 40,86 & 1.00 \\
\hline & Citangkil & 38,20 & 0.93 \\
\hline & Kebonsari & 37,50 & 0.92 \\
\hline & Warnasari & 35,56 & 0.87 \\
\hline
\end{tabular}




\begin{tabular}{|l|l|c|c|}
\hline & Samang Raya & 33,57 & 0.82 \\
\hline Gerogol & Kotasari & 39,66 & 0.97 \\
\hline & Gerogol & 40,05 & 0.98 \\
\hline & Rawa Arum & 36,78 & 0.90 \\
\hline & Gerem & 38,10 & 0.93 \\
\hline Pulomerak & Mekarsari & 39,40 & 0.96 \\
\hline & Tamansari & 35,69 & 0.87 \\
\hline & Lebak Gede & 33,32 & 0.82 \\
\hline & Suralaya & 34,30 & 0.84 \\
\hline
\end{tabular}

(Hasil Pengolahan Data)

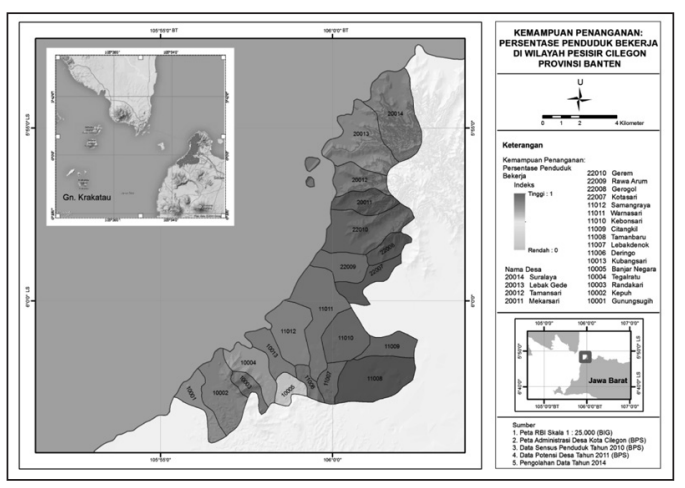

Gambar 7. Peta Kemampuan Penanganan: Persentase Penduduk Bekerja.

sudah bekerja, sedangkan yang terendah adalah Kelurahan Banjar Negara berjumlah $27,27 \%$ dimana hanya memiliki 1.569 dari 5.754 jiwa penduduk yang sudah bekerja.

\subsection{Tingkat Kemampuan Penanganan Total}

Kemampuan Penanganan total adalah penilaian menyeluruh terhadap komponenkomponen yang mempengaruhinya. Dari nilai masing-masing komponen kemampuan penanganan, dapat diperoleh nilai kemampuan penanganan total di tiap unit analisis sehingga diketahui desa/kelurahan apa yang memiliki kapasitas atau kemampuan penanganan tertinggi terhadap bencana tsunami.

Dari hasil kuesioner, diperoleh bobot untuk komponen kesehatan sebesar 0,258; komponen kesiapan bencana sebesar 0,595; dan komponen penduduk bekerja sebesar 0,147 . Bobot komponen kesehatan, kesiapan bencana, dan persentase penduduk dikalikan dengan nilai masing-masing komponen yang kemudian dijumlahkan untuk menghasilkan nilai kemampuan penanganan total.

Komponen kesiapan bencana dinilai memiliki pengaruh yang paling penting terhadap kemampuan penanganan total. Komponen kesehatan memiliki pengaruh yang lebih penting terhadap kemampuan penanganan total jika dibandingkan dengan komponen jumlah penduduk bekerja.

Hasil perhitungan kemampuan penanganan total diketahui bahwa nilai tertinggi berada di Kelurahan Randakari dan Kubangsari dengan nilai 0,52 . Nilai tersebut merupakan hasil kombinasi antara kesehatan yang bernilai $0,15-0,16$; kesiapan bencana bernilai 0,59 dan persentase penduduk bekerja bernilai 0,85-0,86. Kedua kelurahan ini terdapat pada Kecamatan Ciwandan.

Kapasitas terendah berada di Kelurahan Taman Sari dan Desa Deringo yang bernilai 0,15 . Nilai komponen kemampuan penanganan hasil perhitungan adalah kesehatan 0,07 - 0,08; kesiapan bencana 0; dan persentase penduduk bekerja 0,87-0,89. Berdasarkan nilai bobot komponen, maka nilai kesiapan bencana memberikan pengaruh terhadap rendahnya nilai kemampuan penanganan total di Kelurahan Taman Sari dan Desa Deringo. 


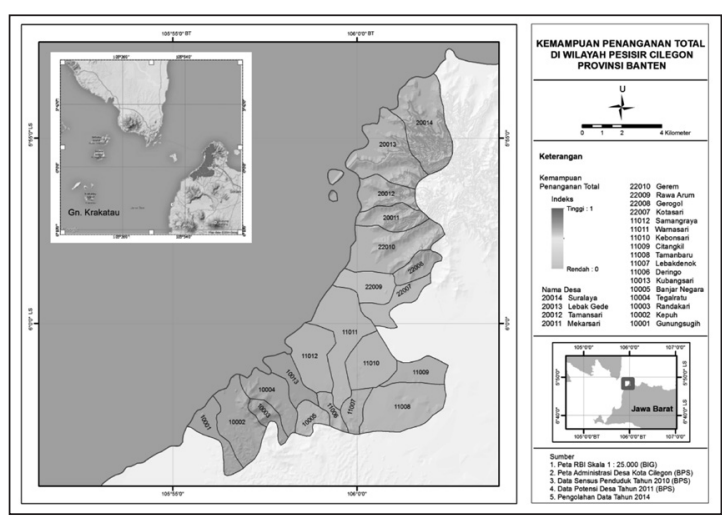

Gambar 8. Peta Kemampuan Penanganan: Total.

\section{KESIMPULAN}

Nilai kemampuan penanganan atau coping capacity pada aspek kesehatan berkisar antara 0,02 sampai dengan 0,79. Rentang nilai kemampuan penanganan pada aspek kesiapan bencana antara 0 sampai dengan 0,59 . Kemampuan penanganan pada aspek jumlah penduduk bekerja bernilai antara 0,67 sampai dengan 1 . Dilihat dari aspek kesehatan, Desa/Kelurahan Rawa Arum paling siap dalam kemampuan penanganan bencana tsunami. Berdasarkan penilaian dalam aspek jumlah penduduk bekerja, Desa/Kelurahan Taman Baru paling siap dalam kemampuan penanganan bencana tsunami. Sementara itu dalam aspek kesiapan bencana, semua desa/ kelurahan di Kecamatan Ciwandan merupakan yang paling siap menghadapi kemungkinan bencana tsunami. Secara keselurahan pada ketiga aspek tersebut, desa/kelurahan Randakari dan Kubangsari yang paling siap dalam kemampuan penanggulangan bencana tsunami.

\section{DAFTAR PUSTAKA}

BPS Kota Cilegon, 2012, Cilegon Dalam Angka 2012, BPS Kota Cilegon: Banten.
Mardiatno, D. dan Yurdinus, P. L. , 2010, Multi-Hazard Risk Assessment Using Spatial Multi Criteria Evaluation (SMCE) Method: a Case Study in Pacitan City, East Java, Indonesia, 6th Report of Tsunami 2004 Indian Ocean.

UN - ISDR, 2002, Disaster Reduction and Sustainable Development. Johannesburg.

UN - ISDR, 2004, Living with Risk, Geneva: UN.

UN - ISDR, 2009, UN - International Strategy for Disaster reduction. Geneva: UN.

Carayannis, G. P., 2003, Near and FarField Effects of Tsunamis Generated by The Paroxysmal Eruptions, Explosions, Caldera Collapses and Massive Slope Failures of The Krakatau Volcano in Indonesia on August 26-27, 1883, Science of Tsunami Hazards, The International Journal of The Tsunami Society, Volume 21, Number 4, page 191-201. Latief, H., Sunendar, H., Hadi, S., Sengara, I., Rahayu, H., 2010, Fenomena, Kajian Bahaya, Kerentanan, dan Risiko serta Upaya Mitigasinya, Mengelola Risiko Bencana di Negara Maritim Indonesia: Bencana Kebumian, Kelautan, dan Atmosferik, Majelis Guru Besar ITB, Bandung. Lazarus, W. N., 2007, A PlaceBased Model for Community Risk Management: Assessing Coping Capacities in Rural Sri Lanka. Thesis, New York: Binghamton University. Post, J., K. Zosseder, G. Strunz, J. Birkmann, N. Gebert, N. Setiadi, H. Z. Anwar, H. Harjono, M. Nur, T. Siagian, 2007, Risk and Vulnerability Assessment to Tsunami and Coastal Hazards in Indonesia: Conceptual Framework and Indicator Development, International Symposium on Disaster in Indonesia, Padang 26 - 27 July 2007. 